\title{
Film Dokumenter Seni Tari Gandrung "Tarian Pembangkit Semangat Bumi Blambangan"
}

\author{
Ahmad Fawaid $^{1}$, Gede Saindra Santyadiputra ${ }^{2}$, Dewa Gede Hendra Divayana ${ }^{3}$ \\ Program Studi Pendidikan Teknik Informatika \\ Jurusan Teknik Informatika \\ Fakultas Teknik dan Kejuruan \\ Universitas Pendidikan Ganesha \\ Email : fawaid1995@gmail.com¹, gsaindras@undiksha.ac.id², hendra.divayana@undiksha.ac.id ${ }^{3}$
}

\begin{abstract}
Abstrak- Tujuan dari penelitian ini adalah untuk: (1) menghasilkan rancangan dan mengimplementasikan hasil rancangan Film Dokumenter Seni Tari Gandrung "Tarian Pembangkit Semangat Bumi Blambangan".(2) mengetahui respon masyarakat terhadap Film Dokumenter Seni Tari Gandrung "Tarian Pembangkit Semangat Bumi Blambangan". Jenis penelitian yang digunakan dalam penelitian ini adalah penelitian dan pengembangan dengan menggunakan metode cyclic strategy. Film Dokumenter Seni Tari Gandrung "Tarian Pembangkit Semangat Bumi Blambangan" menganut jenis film dokumenter sejarah, namun dalam beberapa bagian akan dimunculkan unsur rekonstruksi berbantuan ilustrasi adegan yang di perankan oleh Aktor, di mana film ini nantinya akan menceritakan bagaimana awal mula drama tari Gandrung muncul hingga berkembang sampai sekarang di Desa Kemiren. Dalam film ini tipe film dokumenter yang diusung yaitu tipe expository, di mana nantinya akan ada beberapa tokoh yang menyampaikan langsung fakta dilapangan lewat wawancara yang ditampilkan dalam film ini.Teknik pengumpulan data dilakukan dengan cara observasi, wawancara, studi literatur, angket, dan dokumentasi. Penelitian ini diimplementasikan menggunakan Adobe Premiere Pro CC 2018 sebagai aplikasi pengedit video dan Adobe After Effect CS 6 sebagai aplikasi penambahan efek serta animasi pada video. Hasil penelitian dan pengembangan menunjukkan bahwa Film Dokumenter Seni Tari Gandrung "Tarian Pembangkit Semangat Bumi Blambangan" dalam kriteria baik. Hasil yang diperoleh berdasarkan analisis uji ahli isi, uji ahli media, dan uji respon penonton. Untuk isi dari film dokumenter Seni Tari Gandrung "Tarian Pembangkit Semangat Bumi Blambangan" sudah sesuai dengan realitas. Respon penonton terhadap film dokumenter Seni Tari Gandrung "Tarian Pembangkit Semangat Bumi Blambangan" dapat dikategorikan baik dengan persentase $89.51 \%$.
\end{abstract}

Kata kunci : Cyclic Strategy, Film Dokumenter, Seni Tari Gandrung.

Abstract-The objectives of this study were to: (1) produce a design and implement the results of the design of the Gandrung Dance Art Documentary Film "Dance of the Earth Blambangan Spirit". (2) find out the community response to the Gandrung Dance Art Documentary Film "Blambangan Earth Generation Spirit Dance". The type of research used in this study is research and development using the cyclic strategy method.The documentary documentary of the dance art of Gandrung "Earth Blambangan Spirit Dance" adheres to a type of historical documentary, but in some parts it will bring up elements of reconstruction assisted by illustrated scenes played by Actors, where the film will tell how the Gandrung dance drama appeared developing until now in Kemiren Village. In this film, the type of documentary film that is carried is the expository type, where later there will be several figures who convey the facts directly in the field through the interviews featured in this film. Data collection techniques are carried out by observation, interviews, literature studies, questionnaires, and documentation. This research was implemented using Adobe Premiere Pro CC 2018 as a video editing application and Adobe After Effect CS 6 as an application for adding effects and animations to the video. The results of research and development show that the Gandrung Dance Art Documentary Film "Earth Blambangan Spirit Dance" is in good criteria. The results obtained are based on the analysis of the content expert test, media expert test, and audience response test. For the contents of the documentary film Dance of Gandrung "The Dance of the Earth Blambangan Spirit" is in accordance with reality. The audience response to the Gandrung Dance Art documentary film "Dance of the Earth Blambangan Spirit" can be categorized as good with a percentage of $89.51 \%$. 


\section{ISSN \\ Kumpulan Artikel Mahasiswa Pendidikan Teknik Informatika}

(KARMAPATI)

Keyword's: Cyclic Strategy, Documentary Film, Gandrung Dance Art.

\section{PENDAHULUAN}

Indonesia adalah negara yang memiliki keanekaragaman suku, ras, agama dan keindahan alam. Dan juga memiliki berbagai kesenian-kesenian yang menarik minat wisatawan untuk berkunjung ke Indonesia. Kesenian - kesenian tersebut berupa tarian, rumah adat dari setiap daerah, pakaian adat dan juga musik tradisional. Salah satu kebudayaan yang dimiliki Indonesia yaitu berupa seni tari. "Setiap tarian memiliki ciri yang mencerminkan kekhasan daerah masing-masing. Ciri itu bisa dilihat dari ragam geraknya, tata rias, tata busana, musik pengiring, maupun fungsinya di dalam masyarakat" [1]. Tari tradisional menurut Tumbijo [2] adalah seni budaya yang sejak lama turun temurun telah hidup dan berkembang pada daerah tertentu. Oleh karena itu dapat dijelaskan bahwa tari tradisional adalah kesenian masyarakat yang diwariskan secara turun-temurun dan berkelanjutan pada masyarakat susatu daerah. Kesenian tradisional pada umumnya juga tidak dapat diketahui secara pasti kapan dan siapa penciptanya. Hal ini dikarenakan kesenian tradisional atau keseian rakyat bukan merupakan hasil kreativitas individu, tetapi tercipta secara anonym bersama kreatifitas masyarakat yang mendukungnya. Maka dari itu menjaga, memelihara dan melestarikan kesenian merupakan kewajiban dari setiap individu. Namun pada era perkembangan jaman seperti sekarang ini dalam rangka melestarikan kebudayaan bangsa, seharusnya juga mengikutsertakan peranan sebuah teknologi. Memang Tidak dapat dipungkiri bahwa teknologi memiliki peran penting dalam kehidupan manusia. Seperti teknologi yang bersumber dari televisi, internet dan lain sebagainya. Kita dapat melestarikan budaya dan nilai luhur bangsa dengan teknologi sebagai medianya. Teknologi informasi dan komunikasi dapat menjadi wadah untuk menyebarluaskan informasi mengenai kebudayaan bangsa Indonesia dalam bentuk apapun dengan mudah dan cepat. Seperti contohnya dengan membuat sebuah artikel digital yang membahas tentang kebudayaankebudayaan Indonesia dan kemudian mengunggahnya ke internet, atau juga dengan membuat sebuah film dokumenter yang mengangkat kebudayaan bangsa Indonesia. Sehingga dengan memanfaatkan peranan teknologi, kita dapat memperkenalkan kebudayaan yang kita miliki ke masyarakat yang lebih luas lagi. Oleh karena itu dalam upaya melestarikan kebudayaan bangsa, maka sangat perlu memanfaatkan peranan teknologi untuk mengikuti perkembangan jaman seperti sekarang ini.

Seperti salah satu daerah di Indonesia ini yang juga memiliki berbagai macam kesenian yaitu kota Banyuwangi, yang merupakan kabupaten ujung timur pulau Jawa. Banyuwangi memiliki berbagai kebudayaan kesenian tradisional yang khas, seperti halnya di salah satu desa yang merupakan suku asli Banyuwangi yaitu suku Osing. Suku Osing memiliki tarian khas yaitu tarian Gandrung. Kesenian Gandrung ini merupakan tari perjuangan pada saat era perjuangan untuk melawan penjajah. Tujuannya untuk membangkitkan semangat pada saat melawan penjajah dan tempat berkumpulnya para pejuang untuk membagikan informasi-informasi terkait perjuangan melawan penjajah [3]. Kesenian ini tentu merupakan aset yang perlu dijaga dan dilestarikan oleh semua kalangan. Namun pada kenyataannya masyarakat kurang mengapresiasi terhadap kesenian tradisional tari Gadrung. Hal ini tentu akan berdampak dalam pelestarian kesenian Gandrung di masa yang mendatang. Selain itu juga dalam upaya melestarikan tarian Gandrung penggunaan teknologi kurang dimanfaatkan secara maksimal, sehingga masyarakat minim informasi mengenai kesenian yang sudah mereka miliki.

Berdasarkan hal tersebut, selaku ketua adat di desa Kemiren yaitu bapak Imik berharap agar masyarakat mempunyai rasa memiliki kebudayaannya sendiri. Jangan sampai masyarakat tidak peduli terhadap budaya yang sudah dimiliki, yang nantinya akan menyebabkan hilangnya budaya itu sendiri [4]. Tidak jauh berbeda dengan harapan ibu Temuk selaku penari Gandrung juga berharap kesenian Gandrung selalu dijaga dan dilestarikan bersama. Dewasa ini seni Tari Gandrung sudah hampir punah. Terlihat jarangnya pementasan seni Tari Gandrung dan sudah mulai jarang di undang atau dipentaskan karena sudah sedikit peminat kesenian ini, tetapi tidak berhenti begitu saja dan berharap nantinya kesenian ini dapat kembali di pentaskan Kalangan anak muda juga ikut serta melestarikan tradisi yang sudah ada, jangan sampai terpengaruh dengan kebudayaan-kebudayaan baru yang datang dari luar, sehingga dikawatirkan akan mengurangi kecintaannya terhadap kebudayaannya sendiri [4]. Seiring semakin berkembangnya zaman, generasi muda Indonesia semakin lupa akan keunikan budaya sendiri. Tidak dipungkiri, kemajuan di bidang Ilmu Pengetahuan dan Teknologi (IPTEK) menyebabkan generasi muda lupa akan keunikan budaya sendiri. Hal ini sangat memprihatinkan terhadap kelestarian kesenian dan budaya asli [5].

Berdasarkan hasil dari penyebaran angket yang sudah peneliti lakukan untuk mengetahui kondisi kesenian tarian Gandrung di kalangan masyarakat Banyuwangi terutama di kalangan anak muda, Penyebaran angket dilakukan dibeberapa sekolah yang ada di Kabupaten Banyuwangi yaitu di SMAN 1 Tegaldlimo sebanyak 10 orang responden, SMPN 1 Tegaldlimo sebanyak 10 orang responden dan penyebaran angket juga dilakukan di masyarakat sekitaran Kabupaten Banyuwangi sebanyak 10 orang responden yang dilakukan secara acak. Dari penyebaran angket diperoleh hasil dengan presentase $80 \%$ responden tidak pernah menarikan tari Gandrung, 63\% responden tidak tahu asal dari seni Tari Gandrung ,tetapi $20 \%$ responden pernah melihat seni Tari 


\section{ISSN \\ Kumpulan Artikel Mahasiswa Pendidikan Teknik Informatika}

(KARMAPATI)

Gandrung. 20\% responden pernah menarikan Tari Gandrung dan $77 \%$ responden lebih tertarik menarikan tari modern ketimbang tari tradisional. Kemudian $90 \%$ responden suka menonton film tetapi $33 \%$ responden tidak pernah menonton film dokumenter dan $93 \%$ responden menganggap perlu adanya sebuah film yang mendokumentasikan sebuah kebudayaan khususnya seni tari tradisional. diperoleh hasil bahwa masyarakat dan kalangan anak muda yang ada di Kabupaten Banyuwangi banyak yang tidak mengetahui tentang tarian Gandrung. Bahkan masyarakat dan kalangan anak muda lebih tertarik dengan tarian modern daripada tarian tradisional. Sehingga hal ini berdampak pada kurangnya apresiasi dan perhatian dari masyarakat terhadap kesenian tradisional yang mereka miliki .

Berdasarkan permasalahan tersebut, maka muncul gagasan untuk menjaga, memelihara dan melestarikan sebuah kesenian dengan bantuan teknologi sebagai medianya, salah satunya dengan memproduksi sebuah film dokumenter. Melalui penggunaan media film dokumenter, diharapkan nantinya penyampaian pesan menjadi lebih menarik, komunikatif, mudah dimengerti dan tidak membosankan. Hal ini karena film dokumenter merupakan sarana penyampaian pesan secara kreatif yang merupakan salah satu media komunikasi modern yang menampilkan penggabungan gambar bergerak dengan suara, sehingga penonton dapat mengetahui lebih jelas informasi yang disampaikan dan juga bertujuan untuk mempengaruhi penontonnya sesuai harapan dan informasi yang terkandung di dalamnya. Menurut Nugroh film dokumenter adalah perkembangan dari konsep film non fiksi [6]. Dimana dalam dokumenter selain mengandung fakta, film dokumenter mengandung subyektivitas sipembuatnya. Artinya, apa yang kita rekam memang berdasarkan fakta yang ada.

Film dokumenter sejenis yang mengangkat kesenian tentang tarian sudah pernah dikembangkan sebelumnya oleh peneliti yang lainnya yang berjudul Film Dokumenter Genggong "Sebuah Instrumen Musik Kuno". Film dokumenter tersebut diproduksi menggunakan metode Cyclic Strategy. Tujuan memproduksi film dokumenter tersebut yaitu sebagai media sosialisasi kepada masyarakat dan kalangan anak muda agar menarik minatnya untuk mempelajari alat musik ini dan juga sebagai bentuk dokumentasi visual dari instansi pemerintah yang menaungi bidang kebuadayaan agar dapat ditampilkan pada acara tertentu. Berdasarkan hasil pengujian respon penonton diperoleh persentase sebesar 90,04\% dengan predikat sangat baik. Film ini telah memenuhi kebutuhan informasi target atau audiens mengenai alat musik genggong yang ada di Bali [7].

Berdasarkan gagasan diatas, maka peneliti memiliki ide untuk membuat sebuah film dokumenter dalam rangka menjaga, memelihara dan melestarikan kesenian tari Gandrung yang ada di Kabupaten Banyuwangi. Maka dikembangkan sebuah film dokumenter tentang kesenian tari Gandrung yang berjudul "Film Dokumenter Seni Tari Gandrung: Tarian Pembangkit Semangat Bumi Blambangan" sebagai media untuk memperkenalkan, melestarikan, serta sebagai media dokumentasi.

\section{KAJIAN TEORI}

\section{A. Seni Tari Gandrung}

Kesenian Gandrung adalah merupakan salah satu lambang dan bukti dari sisa perkembangan seni budaya dari kehidupan jaman kekeratonan Blambangan. Bentuk suatu kesenian Gandrung ini, terdapat juga di Bali, yaitu suatu daerah yang pada masa dahulu cukup lama hidup berdampingan dengan Blambangan. Secara historis memang Bali juga merupakan pewaris dari unsur-unsur kebudayaan Majapahit, yang masih dapat dilihat sampai sekarang. Bahkan sebagian besar rakyat bali beranggapan bahwa mereka adalah penerus jalur sejarah mulai dari jaman Kediri sampai Majapahit [7]. Unsur-unsur inilah yang merupakan sebab bahwa Blambangan dan Bali memiliki unsur-unsur kebudayaan yang sama, antara lain Gandrung, Sangyang atau Sang hyang dan beberapa bentuk unsur tehnis permainan suatu jenis kesenian. Hasil wawancara bapak Imik selaku Ketua Adat Desa Kemiren Banyuwangi mengatakan, kesenian Gandrung merupakan tari perjuangan pada saat melawan penjajah .Yang mana bertujuan untuk membangkitkan semangat pada saat penjajah belanda menyerang masyarakat desa. Tarian Gandrung ini melibatkan beberapa penari perempuan yang menari atas kemauan diri sendiri [4].

\section{B. Film Dokumenter}

Film dokumenter merupakan salah satu format film yang mendokumentasikan kenyataan. "Kunci utama dari dokumenter adalah penyajian fakta. Film dokumenter berhubungan dengan orang-orang, tokoh, peristiwa, dan lokasi yang nyata" [8]. Menurut NugrohO film dokumenter adalah perkembangan dari konsep film non fiksi [6]. Dimana dalam film dokumenter mengandung fakta dan mengandung subyektivitas para pembuatnya. Artinya bahwa apa yang direkam memang berdasarkan fakta yang ada. Namun dalam penyajiannya, kita juga memasukkan pemikiran- pemikiran kita, ide-ide kita dan sudut pandang idealisme kita. Dalam program dokumenter terkandung unsur nilai dan faktual. Dalam hal ini faktual berarti nyata, ada dan pernah terjadi. Dokumenter merupakan dokumen dalam hal ini bisa berupa tulisan, catatan, gambar, film, foto, video dari sebuah peristiwa masa lalu yang memiliki makna bagi suatu lingkungan/daerah, sehingga yang dapat mengetahui dokumen ini adalah sebuah dokumenter adalah lingkungan itu sendiri [9]. Berdasarkan uraian diatas dapat disimpulkan bahwa film dokumenter merupakan cara mendokumentasikan atau 


\section{ISSN \\ Kumpulan Artikel Mahasiswa Pendidikan Teknik Informatika}

(KARMAPATI)

merekam sebuah peristiwa berupa fakta yang ada di alam nyata atau sebuah lingkungan yang disajikan secara audio visual bentuk informasi, propaganda, edukasi, dan cara kreatif untuk merepresentasikan realita [3].Dalam program dokumenter terkandung unsur nilai dan faktual .Dalam hal ini faktual berarti nyata, ada dan pernah terjadi. Nilai adalah esensial dan bermakna. Dokumenter adalah dokumen dalam hal ini bisa berupa tulisan, catatan, gambar, film, foto, video dari sebuah peristiwa masa lampau yang memiliki makna bagi suatu lingkungan/daerah, sehingga yang dapat mengetahui dokumen ini adalah sebuah dokumenter adalah lingkungan itu sendiri [10].

Film dokumenter dibagi menjadi delapan jenis. Jenis-jenis film dokumeter, antara lain :

1. Laporan Perjalanan.

2. Sejarah.

3. Biografi :

a) Potret.

b) Biografi.

c) Profil.

4. Nostalgia.

5. Rekonstruksi.

6. Investigasi.

7. Perbandingan dan Kontradiksi.

8. Ilmu Pengetahuan.

9. Buku Harian.

10. Association Picture Story.

11. Dokudrama.

12. Eksperimen Seni.

\section{Sinematografi}

Sinematografi adalah kata serapan dari bahasa Inggris yaitu Cinematography yang berasal dari bahasa Latin kinema (gambar). Sinematografi sebagai ilmu terapan merupakan bidang ilmu yang membahas tentang teknik menangkap gambar dan menggabung-gabungkan gambar, sehingga menjadi rangkaian gambar yang dapat menyampaikan ide (dapat mengemban cerita [11]. Sinematografi mencakup perlakuan sineas terhadap kamera serta stok filmnya. Seorang sineas tidak hanya sekedar merekam sebuah adegan semata namun juga harus mengontrol dan mengatur bagaimana adegan tersebut diambil, seperti jarak, ketinggian, sudut, lama pengambilan, dan sebagainya[12].

\section{Metode Cyclic Strategy}

Metode cyclic strategy merupakan sebuah metode yang ada kalanya suatu tahap perlu diulang kembali sebelum tahap berikutnya dilanjutkan. Pengulangan tahap ini sering disebut dengan loop. Pengulangan tahap ini dimaksudkan untuk menampung umpan balik (feedback) sebelum tahap berikutnya dilanjutkan. Ada kalanya terdapat dua atau lebih loop yang terkandung dalam satu loop yang lebih besar.
Metode cyclic strategy memiliki beberapa tahapan, dapat dilihat pada gambar berikut.

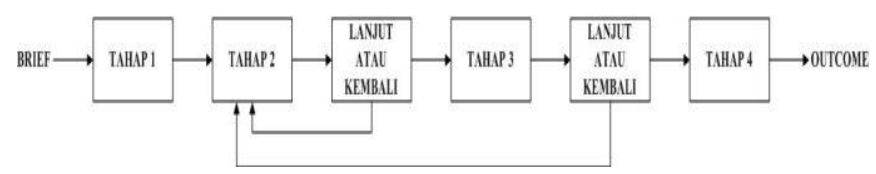

Gambar 1.Metode Cyclic Strategy

\section{METODOLOGI PENELITIAN}

Metode penelitian yang digunakan dalam film dokumenter seni tari gandrung "tarian pembangkit semangat bumi blambangan" adalah metode cyclic strategy. Berikut tahap-tahap dalam metode cyclic strategy.

A. Brief

Di mana pada tahapan ini terdapat beberapa fase yakni :

1. Pemantapan ide

2. Penawaran ide

3. Penemuan masalah

B. Tahap 1 (Pengumpulan Data dan Analisis) Pada tahap 1 terdapat beberapa fase yaitu fase

pengumpulan data dan analisis kebutuhan film.

1. Pengumpulan Data

2. Analisis Kebutuhan Film

C. Tahap 2 (Pra Produksi)

Pada tahap 2 terdapat fase pra produksi. Pra produksi meliputi beberapa tahapan, yaitu perancangan ide cerita, sinopsis, skenario dan storyboard.

\section{Evaluasi 1}

Pada tahap evaluasi 1 akan ada pengujian yang bertujuan mengecek kembali apakah semua bagian dalam tahap 1 dan tahap 2 telah benar-benar terlaksana.

\section{E. Tahap 3 (Produksi dan Pasca Produksi)}

Pada tahap ini terdiri dari fase produksi, pasca produksi. Setelah tahap 3 ini akan melakukan evaluasi terhadap film yang telah dibuat.

\section{F. Evaluasi 2}

Fase pengujian merupakan fase yang dilakukan untuk mendapatkan hasil evaluasi dari perancangan film dokumenter Seni Tari Gandrung "Tarian Pembangkit Semangat Bumi Blambangan”. Dalam evaluasi ini tedapat uji ahli isi, uji ahli media dan uji ahli film dokumenter.

\section{G. Tahap 4}

Pada tahap 4 merupakan tahap akhir sebelum

film disebarluaskan. Pada tahap ini dilakukan proses pengkemasan film ke dalam bentuk DVD sesuai dengan format yang telah di tentukan.

H. Outcome

Tahap terakhir yaitu dipublikasikan ke 


\section{ISSN \\ Kumpulan Artikel Mahasiswa Pendidikan Teknik Informatika}

masyarakat luas. Pada tahap outcome ini akan dilakukan publishing terhadap film yang telah di buat.

\section{Uji Respon Penonton}

Uji Respon Penonton dilakukan untuk mengetahui kepuasan penonton dan tanggapan penonton tentang film dokumenter seni Tari Gandrung "Tarian Pembangkit Semangat Bumi Blambangan". Berikut rumus yang digunakan dalam menghitung hasil dari pengujian .

$$
\text { Persentase }=\frac{\text { Skor } \text { Perolehan }}{\text { Skor Maksimal }} \times 100 \%
$$

Dimana hasil akhir perhitungan nantinya akan berupa persentase yang nantinya akan dijadikan jawaban sesuai dengan rumusan masalah dari penelitian ini. Berikut ketetapan katagori tingkat pencapaian film sebagai media visual dapat di lihat pada table 3.1. [9]

Tabel 3.1. Konversi Tingkat Pencapaian
\begin{tabular}{|l|l|l|}
\hline $\begin{array}{c}\text { Tingkat } \\
\text { Pencapaian }\end{array}$ & Kualifikasi & Keterangan \\
\hline $90 \%-100 \%$ & Sangat Baik & $\begin{array}{l}\text { Tidak perlu } \\
\text { direvisi }\end{array}$ \\
\hline $75 \%-89 \%$ & Baik & $\begin{array}{l}\text { Tidak perlu } \\
\text { direvisi }\end{array}$ \\
\hline $65 \%-74 \%$ & Cukup & Direvisi \\
\hline $55 \%-64 \%$ & Kurang & Direvisi \\
\hline $0 \%-54 \%$ & $\begin{array}{l}\text { Sangat } \\
\text { Kurang }\end{array}$ & Direvisi \\
\hline
\end{tabular}

\section{HASIL \& PEMBAHASAN}

\section{A. HASIL PENELITIAN}

Film dokumenter seni tari gandrung "tarian pembangkit semangat bumi blambangan" ini mampu memberikan informasi mengenai seni tari gandrung yang ada di Desa kemiren pada khusus nya dan Kabupaten Banyuwangi pada umumnya terutama tentang sejarah kemunculan seni tari gandrung di Desa kemiren kepada mayarakat Banyuwangi maupun luar Banyuwangi dan sekaligus sebagai media untuk melestarikan seni tari gandrung itu sendiri. Dalam penelitian ini mengunakan metode penelitian model cyclic strategy dengan hasil penelitian sebagai berikut:

\section{Hasil Tahap Brief}

Brief merupakan tahap persiapan awal untul melakukan penelitian ini. Di mana tahap awal dari film documenter "tarian pembangkit semangat bumi blambangan" yaitu pemantapan ide dan penawaran ide/topik terhadap Jurusan
Teknik Informatika. Ide/topik tersebut diajukan dan disetujui pada tanggal 23 Juni 2017. Kemudian dilakukan riset awal terkait permasalah yang terjadi pada seni tari gandrung yang ada di Desa Kemiren.

\section{Hasil Tahap 1 (Pengumpulan Data dan \\ Analisis Kebutuhan Film)}

Pada tahap 1 ini terdapat beberapa fase yaitu pengumpulan data dan analisis. Di mana hasil dari fase tersebut dapat dijabarkan sebagai berikut.

\section{Pengumpulan data}

Dalam pembuatan film dokumenter ini menggunakan beberapa teknik pengumpulan data. Teknik pengumpulan data dijabarkan sebagai berikut.

a. Observasi.

Observasi dilakukan penulis selama satu minggu kepada sanggar-sanggar tari dan rumah-rumah narasumber dengan cara mengunjungi langsung rumah dan sanggar seni tari yang masih dapat dijumpai di Desa Kemiren. Adapun sanggar tari dan rumah narasumber yang telah diobservasi yaitu:

1. Sanggar Sopo Ngiro yang bertempat di Dusun Krajan, Desa Kemiren, Kecamatan Glagah, Kabupaten Banyuwangi.

2. Rumah Bapak Rianto Agus yang bertempat di Dusun Krajan, Desa Kemiren, Kecamatan Glagah, Kabupaten Banyuwangi.

3. Rumah Bapak Suhaimik yang bertempat di Dusun Krajan, Desa Kemiren, Kecamatan Glagah, Kabupaten Banyuwangi.

4. Rumah Bapak Sugiarta yang bertempat di Dusun Krajan, Desa Kemiren, Kecamatan Glagah, Kabupaten Banyuwangi.

5. Rumah Ibu Temuk Misti yang bertempat di Dusun Krajan, Desa Kemiren, Kecamatan Glagah, Kabupaten Banyuwangi.

b. Wawancara

Wawancara dilakukan langsung terhadap akademisi seni, seniman dan juga budayawan, baik itu penari gandrung, penabuh gamelan seni tari gandrung serta orang - orang yang berkompeten di bidang tari, selain itu pula ke guru kesenian yang ada di sekolah menengah yang ada di sekitaran Desa Kemiren, guna mendapatkan data-data mengenai drama tari gandrung yang digunakan dalam penelitian ini. Dalam wawancara ini juga dijadikan sebagai acuan untuk menentukan narasumber utama dalam film dokumenter seni tari gandrung "tarian pembangkit semangat bumi blambangan". Hasil wawancara yang dilakukan penulis dapat dilihat pada lampiran 2. Adapun narasumber yang diwawancarai untuk menunjang penelitian ini adalah sebagai berikut. 


\section{ISSN \\ Kumpulan Artikel Mahasiswa Pendidikan Teknik Informatika}

(KARMAPATI)

1. Temuk Misti (Penari Tari Gandrung). Wawancara dilakukan di Sanggar Tari Sopo Ngiro di Desa Kemiren, Kecamatan Glagah, Kabupaten Banyuwangi.

2. Sugiarta (Penabuh Gamelan Tari Gandrung). Wawancara dilakukan di Desa Kemiren, Kecamatan Glagah, Kabupaten Banyuwangi.

3. Suhaimik (Ketua Adat Desa Kemiren). Wawancara dilakukan di Desa Kemiren, Kecamatan Glagah, Kabupaten Banyuwangi.

4. Rianto Agus (Sejarawan). Wawancara dilakukan di Desa Kemiren, Kecamatan Glagah, Kabupaten Banyuwangi.

c. Penyebaran Angket Kuesioner

Penyebaran angket kuesioner dilakukan guna mendapatkan data-data awal dari masyarakat umum utamanya generasi muda tentang pengetahuannya terhadap seni tari gandrung guna memperkuat permasalahan yang terjadi di kalangan generasi muda terhadap seni tari gandrung. Penyebaran angket kuesioner difokuskan di sekitaran Desa Kemiren yaitu ke sekolah-sekolah menengah dan beberapa taman kota. Total keseluruhan jumlah responden sebanyak 30 responden. Hasil penyebaran angket observasi awal dapat dilihat pada lampiran 3. Hasil angket ini dikalkulasikan menjadi sebuah data awal dari generasi muda (11-18 tahun) terkait pengetahuannya terhadap seni tari gandrung.

d. Studi Pustaka

Studi pustaka dilakukan untuk mengumpulkan sumber tertulis maupun tidak tertulis seperti buku, jurnal, internet, majalah, koran, dan artikel terkait, baik yang dipublikasikan mau pun non publikasi.

e. Dokumentasi

Dokumentasi dilakukan secara terjadwal untuk wawancara dengan narasumber sedangkan dokumentasi selain itu dilakukan secara acak.

2. Hasil Analisis Kebutuhan Film.

Dari hasil analisis terhadap data yang terkumpul maka ditetapkan beberapa subjek film yang dibutuhkan dalam proses pembuatan film dokumenter seni tari gandrung "tarian pembangkit semangat bumi blambangan"sesuai dengan hasil analisis yang telah dilakukan penulis. Adapun subjek film tersebut yaitu:

a. Penentuan talent

Adapun talent yang terlibat dalam film dokumenter seni tari gandrung "tarian pembangkit semangat bumi blambangan" yaitu:

1. Narasumber

Narasumber dipilih dengan pertimbangan dan tujuan yang relevan dengan arah dokumentasi. Adapun narasumber dalam film dokumenter seni tari gandrung "tarian pembangkit semangat bumi blambangan" yaitu: a. Temuk Misti (Penari Seni Tari Gandrung). b. Suhaimik (Ketua Adat Desa Kemiren).

c. Sugiarta (Penabuh Gamelan Seni Tari Gandrung).

d. Rianto Agus (Sejarawan ).

e. Anak-anak anggota sanggar Sopo Ngiro

2. Pementasan Seni Tari Gandrung: Anggota Sanggar Sopo Ngiro.

3. Pelatihan Seni Tari Gandrung:

a. Pembina: Temuk Misti.

b. Peserta: Anak-anak anggota sanggar Sopo Ngiro.

b. Penentuan lokasi

Lokasi shooting pembuatan film dokumenter seni tari gandrung "tarian pembangkit semangat bumi blambangan" ini lebih banyak menggunakan lokasi shooting indoor. Lokasi shooting berpusat di Desa Kemiren, Kecamatan Glagah, Kabupaten Banyuwangi karena fokus film ini untuk mengangkat seni tari gandrung yang ada di Desa Kemiren. Adapun tempat lokasi Shooting pembuatan film dokumenter seni tari gandrung "tarian pembangkit semangat bumi blambangan" yaitu:

1. Sanggar Sopo Ngiro (Outdoor).

2. Rumah kediaman narasumber Temuk Misti (Indoor).

3. Rumah kediaman narasumber Sugiarta (Indoor).

4. Rumah kediaman narasumber Suhaimik (Indoor).

5. Rumah kediaman narasumber Rianto Agus (Indoor).

6. Daerah Persawahan di sekitaran Dusun Krajan, Desa Kemiren (Outdoor).

7. Dinas Kebudayaan Kabupaten Banyuwangi (Indoor).

8. Obyek Wisata Pantai Pulau merah dan Grand Watu Dodol, Kabupaten Banyuwangi (Outdoor).

9. Kantor Pemerintahan Dinas Banyuwangi (Outdoor).

10. Alun-alun blambangan dan taman kota sritanjung Banyuwangi (Outdoor).

11. Lingkungan Desa Kemiren, Kecamatan Glagah, Kabupaten Banyuwangi (Indoor/Outdoor).

12. Desa Wisata Alas Malang, Kecamatan Singonjuruh, Kabupaten Banyuwangi (Outdoor)

13. Rumah Bapak Muhaimin , Kecamatan Glagah, Kabupaten Banyuwangi (Outdoor)

c. Penentuan Peralatan alat Adapun peralatan yang digunakan dalam pembuatan film dokumenter seni tari gandrung "tarian pembangkit semangat bumi blambangan" yaitu:

1. Kamera DSLR Canon $70 \mathrm{D}$

2. Kamera DSLR Canon $60 \mathrm{D}$

3. Kamera DSLR Nikon D5500

4. Kamera DSLR Nikon D700

5. Kamera Mirrorless Sony a6000

6. Lensa EF 55 mm (fix)

7. Lensa EF 18-55 mm (zoom)

8. Lensa EF 17-50 mm (zoom)

9. Lensa EFS 18-135mm (zoom)

10. Lensa EFS 10-18mm (wide) 


\section{Kumpulan Artikel Mahasiswa Pendidikan Teknik Informatika

11. Drone Dji Phantom

12. Tripod

13. Rode microphone

14. Komputer. Dengan spesifikasi sebagai berikut: a.Proccesor Intel(R) Core(TM) i5

b.Memory (RAM) 8GB DDR5

c.Harddisk 1TB

d.Msi GTX 720Ti (2GB)

e.DVD/RW

\section{d. Penentuan Crew}

Crew film sangat dibutuhkan dalam membantu proses produksi yaitu pada saat shooting. Adapun crew film dalam pembuatan film dokumenter seni tari gandrung "tarian pembangkit semangat bumi blambangan" yaitu:

1. Produser : Ahmad Fawaid

2. Penulis Skenario : Ahmad Fawaid

3. Sutradara : Ahmad Fawaid

4. Cameraman 1 : Alfan Hisbullah

5. Cameraman 2 :PandeGede Erick S

6. Cameraman 3 : Ahmad Fawaid

7. Editor : Ahmad Fawaid

8. Drone Pilot : Widi Hartono

\section{e. SWOT (Strenght, Weakness, Opportunity, Treat)}

1. Strength (Kekuatan)

a) Film ini mengangkat seni tari gandrung yang ada di Banyuwangi sehingga menggugah penonton untuk mencari tahu lebih banyak tentang kebudayaan tradisional yang ada di Banyuwangi ataupun daerah Indonesia lainnya, khususnya seni tari gandrung Desa Kemiren.

b) Terjalinnya komunikasi yang baik dengan narasumber, sehingga dalam proses pembuatan film ini mendapatkan dukungan penuh dari narasumber.

2. Weakness (Kelemahan)

a) Keterbatasan dana dalam proses penggarapan film.

b) Jumlah crew yang terbatas dan masih amatiran.

c) Alat yang digunakan dalam pembuatan film ini juga masih terbilang belum maksimal.

d) Jadwal pertunjukkan seni tari gandrung ini yang tidak menentu dikarenakan pementasannya yang telah jarang di lakukan.

3. Opportunity (Peluang)

a) Nantinya film ini akan menjadi media sosialisasi dalam bentuk film dokumenter yang mengangkat seni tari gandrung.

b) Dapat digunakan untuk mensosialisasikan seni tari gandrung oleh organisasi atau perorangan yang membutuhkan, contohnya Dinas Kebudayaan Provinsi Banyuwangi.

4.Threat (Ancaman) a) Dalam menentukan jadwal pengambilan gambar untuk momen pertunjukkan seni tari Gandrung sulit untuk dilakukan dikarenakan pementasannya yang telah jarang dilakukan.

b) Kesenian ini di laksanakan di luar ruangan. Sehingga pengaruh perubahan cuaca sangat mempengaruhi dalam pagelaran kesenian Gandrung.

f. STP (Segmentating, Targeting, Positioning)

1) Segmentating

a) Geografis

Ditujukkan untuk semua wilayah yang ada di Indonesia serta nantinya akan disertakan subtitle berbahasa indonesia agar segementasi target pemasaran bisa mencapai seluruh negeri.

b) Demografis

Film ini dapat ditonton oleh usia 8 s.d 60 tahun serta penonton mencangkup kaum laki-laki maupun perempuan dengan segala jenis pekerjaan tanpa ada batasan.

c) Psikografis

Dapat disaksikan oleh segala lapisan sosial.

\section{2) Targeting}

Target utama penyebaran film adalah badan / organisasi / komunitas yang memiliki tujuan untuk melestarikan kebudayaan yang ada di Banyuwangi. Dengan begitu baik target utama maupun penulis akan saling terbantu, di mana target utama akan mendapatkan sebuah media audio visual untuk melakukan sosialisasi terkait seni tari gandrung dan upaya pelestariannya begitu pula dengan penulis, akan terbantu dalam penyebarluasan film ini ke target yang lebih umum yaitu masyarakat luas. Di mana target umum tidak dibatasi, hanya berpatok pada usia yang berada di kisaran 8 s.d 60 tahun.

3) Positioning

Film ini akan menjadi film pertama yang mengangkat mengangkat sejarah seni tari Gandrung di Desa Kemiren yang merupakan cikal bakal seni tari pertama yang ada di Banyuwangi selain itu film ini juga akan mengajak penonton untuk peduli dan ikut melestarikan seni tari tersebut.

\section{Hasil Tahap 2 (Pra Produksi)}

Pada tahap ini terdapat fase pra produksi. Dalam tahap ini, konsep direalisasikan dalam bentuk sinopsis sebelum dituangkan ke dalam bentuk ide/konsep film, storyline, scenario, dan storyboard. Adapaun Hasil dilakukan pada tahapan ini antara lain:

\section{Ide/Konsep Film}

Ide cerita merupakan bagian dasar untuk pembuatan sebuah film dokumenter. Ide cerita dari pembuatan film dokumenter seni tari gandrung "tarian pembangkit semangat bumi blambangan" dibuat berdasarkan cerita fakta hasil observasi dan wawancara dengan Temuk Misti 


\section{ISSN \\ Kumpulan Artikel Mahasiswa Pendidikan Teknik Informatika}

(KARMAPATI)

(Kemiren), Sugiarta (Kemiren) selaku seniman seni tari Gandrung desa Kemiren dan Suhaimik (Kemiren) sebagai ketua adat desa yang ada di Desa Kemiren.

2. Sinopsis

Sinopsis film Dokumenter Seni Tari Gandrung "Tarian Pembangkit Semangat Bumi Blambangan" merupakan ringkasan dari cerita yang akan ditampilkan dalam film.

\section{Storyboard}

Storyboard adalah kumpulan grafis dalam bentuk ilustrasi atau gambar yang ditampilkan secara berurutan untuk tujuan mempravisualkan film, animasi ataupun interaktif.

\section{Skenario}

Dari skenario dapat diketahui soal jalan cerita, bukan hanya soal karakterisasi pemain, melainkan juga gambaran perkiraan pembiayaan, atau bahkan kira-kira siapa yang akan memainkan.

\section{Hasil Evaluasi 1}

Evaluasi 1 dilakukan bertujuan untuk menge-cek bahwa semua proses yang berada pada tahap 1 dan 2 sudah dikerjakan atau terlaksana. Evaluasi dilakukan menggunakan uji instrumen peneliti.

\section{Hasil Tahap 3 (Produksi dan Pasca Produksi)}

Berikut hasil dari fase-fase tersebut.

a. Produksi

Tahap produksi film dokumenter Seni Tari Gandrung "Tarian Pembangkit Semangat Bumi Blambangan" merupakan proses yang dilakukan sesuai dengan skenario dan storyboard yang telah di buat pada tahap pra produksi.

b. Pasca Produksi

Tahap-tahap yang ada pada pasca produksi dijelaskan sebagai berikut.

1) Tahap Video Editing

Tahap video editing film dokumenter

Seni Tari Gandrung "Tarian Pembangkit mengunakan software Adobe Premiere Pro CC 2018. Proses editing video dalam film dokumenter Seni Tari Gandrung "Tarian Pembangkit dapat dilihat pada Gambar 2.

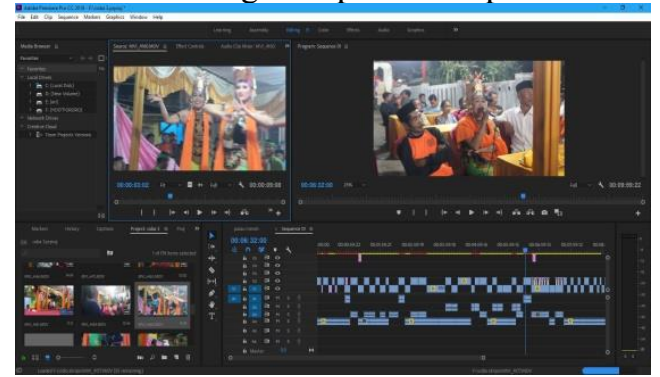

Gambar 2. Proses Video Editing Menggunakan Adobe Premiere Pro Cc 2018
Dalam tahap editing video ini juga terdapat proses color grading (perubahan warna) yang bertujuan menambah ketajaman warna dalam unsur visual sehingga dapat memberikan kesan yang menarik.

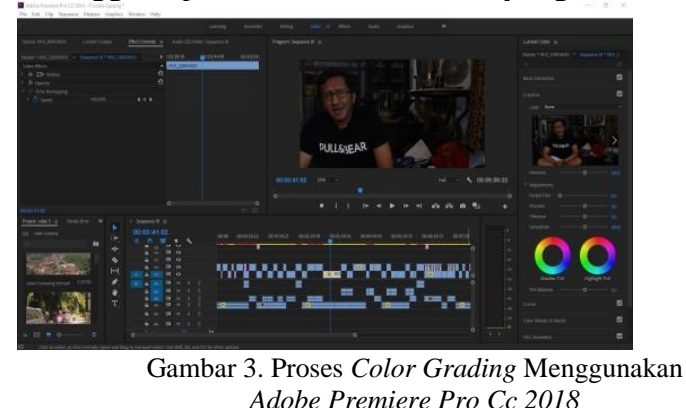

2) Tahap Sound Editing

Tahap sound editing film dokumenter Seni Tari Gandrung "Tarian Pembangkit Semangat Bumi Blambangan" mengunakan software Adobe Audition Pro CS6. Pada Gambar 4. menunjukan proses editing audio guna membersihkan suara noise

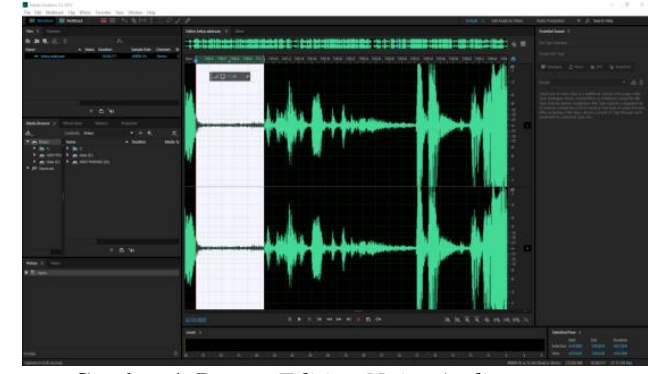

Gambar 4. Proses Editing Noise Audio

Menggunakan Adobe Audition Pro CS6

\section{3) Tahap Mixing}

Tahap mixing dalam pembuatan film

dokumenter Seni Tari Gandrung "Tarian Pembangkit Semangat Bumi Blambangan" ini menggunakan software Adobe Premiere Pro Cc 2018. Proses mixing dapat dilihat pada Gambar 5.

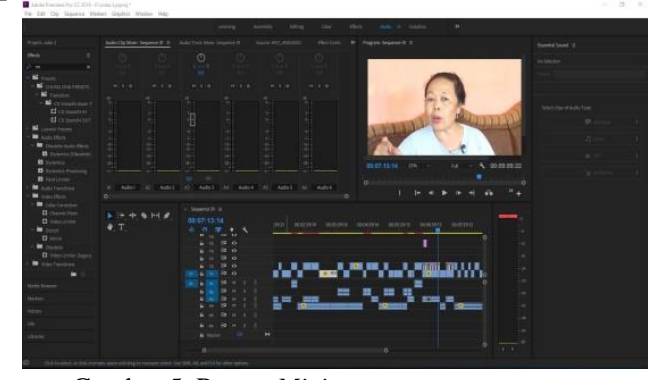

Gambar 5. Proses Mixing

Menggunakan Adobe Premiere Pro Cc 2018

4) Rendering

Proses rendering film dokumenter 


\section{Kumpulan Artikel Mahasiswa Pendidikan Teknik Informatika \\ ISSN}

(KARMAPATI)

Seni Tari Gandrung "Tarian Pembangkit Semangat Bumi Blambangan" dilakukan setelah proses mixing selesai. Proses rendering dapat dilihat pada Gambar 6.

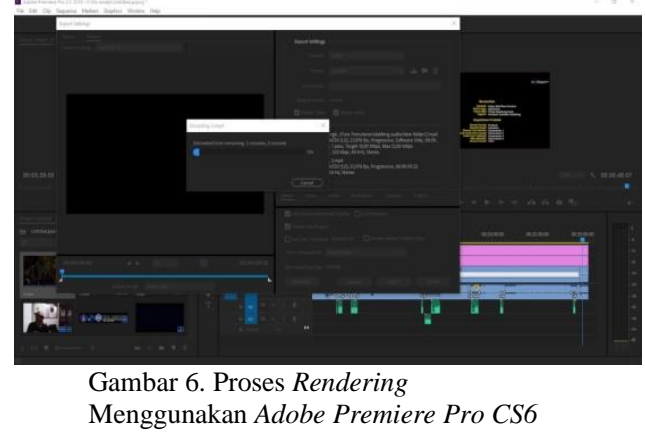

6. Hasil Evaluasi 2 (Uji Ahli Isi dan Media)

Tahap Evaluasi yang ke dua ini merupakan tahap pengujian terhadap film dokumenter yang telah dibuat. Pengujian dilakukan terhadap beberapa ahli yaitu :

a. Uji Ahli Isi

Pengujian ini dilakukan dari tanggal 25 Juni 2019. Pengujian ahli isi film dokumenter ini dilakukan oleh 2 orang penguji. Namun bapak Suhaimik ditambahkan keterangan yang berisi saran yaitu, untuk mengenal gamelan tari gandrung lebih dalam mungkin nanti bisa dibuatkan film khusus tentang pengenalan gamelan tari gandrung. Sehingga dapat disimpulkan bahwa rata-rata persentase keseluruahan adalah $1 \%$. dengan predikat sangat tinggi dan tidak perlu adanya revisi.

b. Uji Ahli Media

Pengujian ini dilakukan dari tanggal 1 Juli 2019. Pengujian ahli media film dokumenter ini dilakukan oleh 2 orang penguji. Ada sedikit saran dari penguji ahli media, Namun, ada sedikit saran dari penguji ahli media, yaitu saran dari Bapak I Gede Mahendra Darmawiguna, S.Kom., M.Sc. adalah dalam pengambilan gambar yang harusnya tidak terpotong-potong lebih diperhatikan komposisinya agar terlihat proporsional dan menarik. Sedangkan dari ibu Ni Ketut Kertiasih, S. Si., M. Pd. mengomentari pada dalam pengambilan gambar yang masih blur dan lebih diperhatikan komposisi pencahayaan nya agar terlihat proporsional dan menarik. Berdasarkan rekapitulasi penilaian dari masingmasing penguji ahli media dapat disimpulkan bawa rata-rata persentase keseluruahan adalah $0,66 \%$ dengan predikat tinggi dan tidak perlu adanya revisi.

c. Uji Ahli Film Dokumenter

Pengujian ini dilakukan pada tanggal 21 Juni 2019. Oleh satu orang penguji. Namun pada pernyataan nomer 2 dan nomer 3 dicantumkan pujian dan saran yang berisi, pada pernyataan nomer 2 yaitu, sudut pandang dan tujuan penyampainnya bagus, serta pada nomer 3 yaitu latih kembali tehnik/komposisi pengambilan gambar dalam wawancara. Berdasarkan rekapitulasi penilaian dari masing-masing penguji ahli film dokumenter dapat disimpulkan bawa ratarata persentase keseluruahan adalah $1 \%$ dengan predikat sangat tinggi dan tidak perlu adanya revisi.

7. Hasil Tahap 4 (Burning, Label DVD dan Sampul DVD)

Pada tahap 4 merupakan tahap akhir dari pembuatan film dokumenter.

a. Hasil Desain Label DVD

Sesuai dengan konsep yang telah dirancang dengan beberapa tambahan, maka didapatkan hasil implementasi dari desain label DVD film dokumenter Seni Tari Gandrung "Tarian Pembangkit Semangat Bumi Blambangan" pada Gambar 7

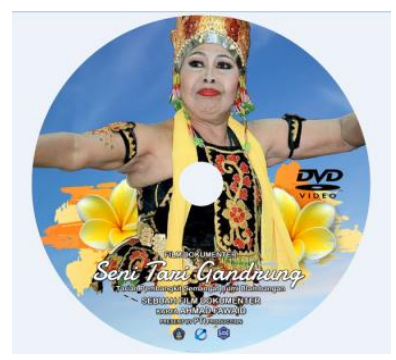

Gambar 7. Hasil Label DVD Seni Tari Gandrung "Tarian Pembangkit Semangat Bumi Blambangan”

b. Hasil Desain Cover Sampul

Sesuai dengan konsep yang telah dirancang dengan beberapa tambahan, maka didapatkan hasil implementasi dari desain cover sampul DVD film dokumenter Seni Tari Gandrung "Tarian Pembangkit Semangat Bumi Blambangan" pada Gambar 8.

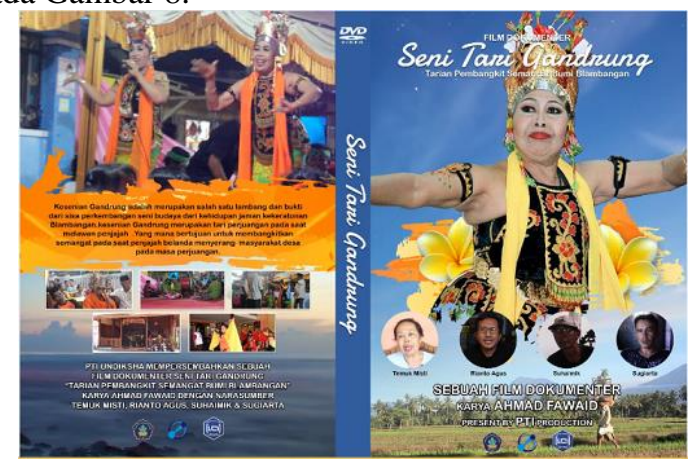

Gambar 8. Hasil Desain Cover Sampul Seni Tari Gandrung "Tarian Pembangkit Semangat Bumi Blambangan"

\section{Hasil Outcome}

Tahapan terakhir pada pembuatan film dokumenter Seni Tari Gandrung "Tarian Pembangkit Semangat Bumi Blambangan" dilakukan tahapan publikasi yang mengunakan media promosi berupa poster. Berikut adalah hasil poster dapat dilihat pada Gambar 9. 


\section{ISSN \\ Kumpulan Artikel Mahasiswa Pendidikan Teknik Informatika}

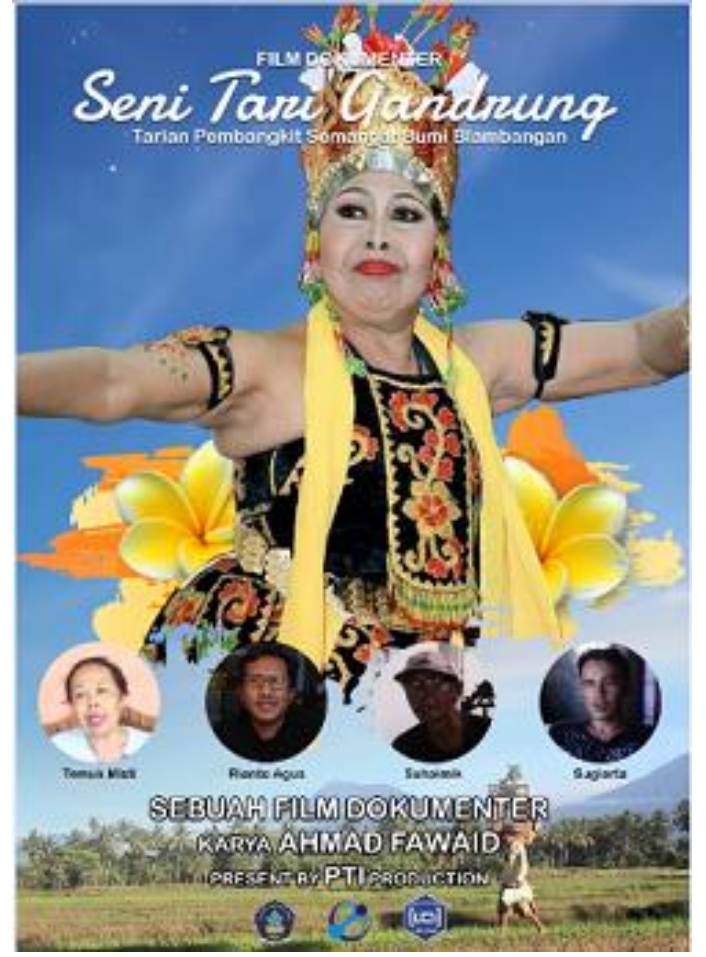

Gambar 9. Hasil Poster Film Dokumenter Seni Tari Gandrung "Tarian Pembangkit Semangat Bumi Blambangan”

\section{Hasil Uji Respon Penonton}

Berdasarkan data uji respon penonton yang

telah diujikan terhadap 30 orang, diperoleh hasil rata-rata persentase keseluruhan yaitu $89,51 \%$ dengan tingkat pencapaian baik.

\section{B. PEMBAHASAN}

Film Dokumenter Seni Tari Gandrung "Tarian Pembangkit Semangat Bumi Blambangan" menganut jenis film dokumenter sejarah, namun dalam beberapa bagian akan dimunculkan adegan yang diperankan oleh aktor, di mana film ini nantinya akan menceritakan bagaimana awal mula seni tari Gandrung muncul hingga berkembang sampai sekarang di Desa Kemiren. Dalam film ini tipe film dokumenter yang diusung yaitu tipe expository, di mana nantinya akan ada beberapa tokoh yang memperkenalkan Desa Kemiren, memperkenalkan seni tari Gandrung, menyampaikan sejarah dari seni tari Gandrung yang ada di Desa Kemiren dan perkembangannya hingga sekarang. Semua bagian tersebut akan ditampilkan lewat wawancara langsung dengan berbagai narasumber seperti, beberapa seniman seni tari Gandrung asal Desa Kemiren dan akademisi di bidang seni yang juga juga pernah menggangkat seni tari Gandrung dalam karya tulisannya atau pernah belajar dan melestarikan seni tari Gandrung. Selain itu nantinya akan disertakan ilustrasi yang bertujuan untuk memudahkan penonton dalam menangkap informasi yang disampaikan. Dalam pengembangan film dokumenter seni tari gandrung "tarian pembangkit semangat bumi blambangan". menggunakan metode
Volume 8, Nomor 2, Tahun 2019

cyclic strategy. Metode cyclic strategy memiliki beberapa tahapan, antara lain :

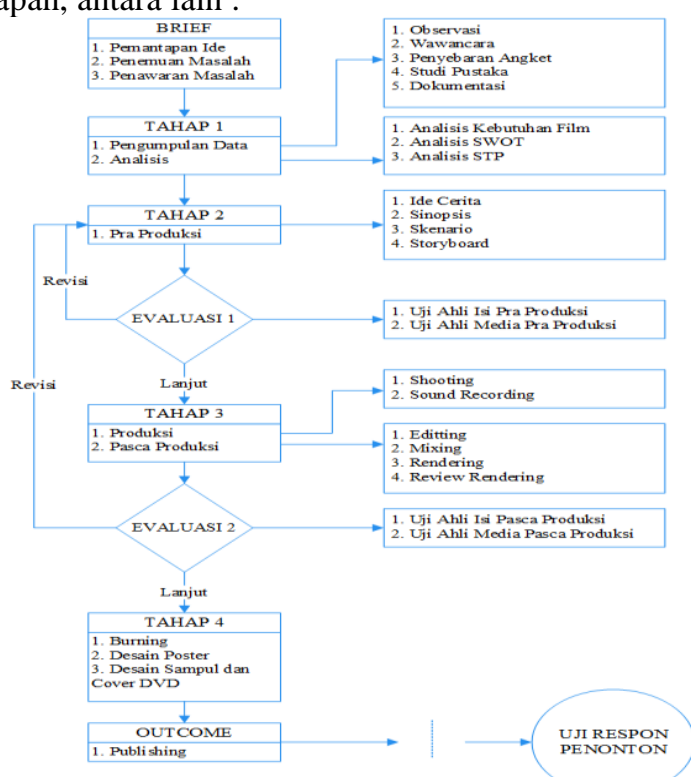

Pada tahap brief melakukan pengajuan ide atau topik terhadap ketua Jurusan Pendidikan Teknik Informatika. Setelah ide atau topik sudah diterima selanjutnya lanjut ke tahap 1 yaitu melakukan pengumpulan data dan analisis kebutuhan film. Pada tahap 2 dilakukan tahapan pra produksi yang meliputi penentuan ide cerita, sinopsis, skenario dan storyboard. Selanjutnya dilakukan evaluasi 1 untuk menguji tahap 1 dan tahap 2 .

Tahap 3 merupakan tahapan produksi dilanjutkan pasca produksi film dokumenter seni tari gandrung "Tarian Pembangkit Semangat Bumi Blambangan". Setelah dilakukannya uji ahli isi terhadap dua orang, diperoleh hasil pengujian menggunakan angket dengan persentase rata-rata penilaian yang diperoleh $1 \%$. Berarti bila dikonversikan ke dalam tabel konversi, berada pada kualifikasi sangat tinggi. Hal ini berarti isi cerita pada film dokumenter seni tari gandrung "Tarian Pembangkit Semangat Bumi Blambangan" tidak perlu direvisi dan menunjukan bahwa isi informasi di dalam film dokumenter seni tari gandrung "Tarian Pembangkit Semangat Bumi Blambangan" sudah sesuai dan layak untuk dilanjutkan. Namun bapak Suhaimik ditambahkan keterangan yang berisi saran yaitu, untuk mengenal gamelan tari gandrung lebih dalam mungkin nanti bisa dibuatkan film khusus tentang pengenalan gamelan tari gandrung.

Pada hasil uji media film dokumenter seni tari gandrung "Tarian Pembangkit Semangat Bumi Blambangan" yang dilakukan oleh dua orang menyatakan bahwa film tersebut sudah sesuai dan memperoleh rata-rata persentase penilaian sebesar 0,66\%. Dan bila dikonversikan ke dalam tabel konversi, berada pada kualifikasi tinggi. Namun, ada sedikit saran dari penguji ahli media, yaitu saran dari Bapak I Gede Mahendra Darmawiguna, S.Kom., M.Sc. adalah dalam pengambilan 


\section{ISSN \\ Kumpulan Artikel Mahasiswa Pendidikan Teknik Informatika}

(KARMAPATI)

gambar yang harusnya tidak terpotong-potong lebih diperhatikan komposisinya agar terlihat proporsional dan menarik. Sedangkan dari ibu Ni Ketut Kertiasih, S. Si., M. Pd. mengomentari pada dalam pengambilan gambar yang masih blur dan lebih diperhatikan komposisi pencahayaan nya agar terlihat proporsional dan menarik.

Selanjutnya pada hasil uji film dokumenter, film dokumenter seni tari gandrung "tarian pembangkit semangat bumi blambangan" yang dilakukan oleh satu orang menyatakan bahwa film tersebut sudah sesuai dan memperoleh rata-rata persentase penilaian sebesar $1 \%$. Dan bila dikonversikan ke dalam tabel konversi, berada pada kualifikasi sangat Tinggi. Berarti film yang dikembangkan ini bisa dinyatakan sebagai film dokumenter dan telah memenuhi syarat sebagai film dokumenter yang baik dan benar karena memenuhi kaedahkaedah yang harus dipenuhi sebagai film dokumenter. Namun pada pernyataan nomer 2 dan nomer 3 dicantumkan pujian dan saran yang berisi, pada pernyataan nomer 2 yaitu, sudut pandang dan tujuan penyampainnya bagus, serta pada nomer 3 yaitu latih kembali tehnik/komposisi pengambilan gambar dalam wawancara.

Pada tahap 4 dilakukan proses mastering file yang sudah dirender, kemudian dikemas dalam bentuk DVD dan dapat dipublikasikan. Dilanjutkan ke tahap outcome yang merupakan tahap terakhir pada pembuatan film dokumenter seni tari gandrung "tarian pembangkit semangat bumi blambangan". Tahapan outcome ini adalah pempublikasian film dokumenter seni tari gandrung "tarian pembangkit semangat bumi blambangan" dalam bentuk DVD yang telah dibuat dan disosialisasikan dengan media poster.

Uji respon penonton adalah pengujian untuk mengetahui bagaimana respon penonton setelah menonton film dokumenter seni tari gandrung "tarian pembangkit semangat bumi blambangan". Untuk film dokumenter seni tari gandrung "tarian pembangkit semangat bumi blambangan" uji respon dilakukan dengan menggunakan uji skala likert. Pada uji respon penonton film dokumenter ini peneliti melakukan pengujian terhadap 30 orang responden di beberapa tempat umum yang ada di Wilayah sekitaran Desa Kemiren antara lain Taman kota sritanjung dan RTH desa Kemiren serta masyarakat umum dengan rentangan usia 12 tahun keatas pada tanggal 5-7 Juli 2019. Hasil dari keseluruhan uji respon penonton diperoleh presentase sebanyak $89.51 \%$ yang dikonversikan ke dalam tabel konversi menyatakan pencapaian baik. Untuk hasil rekapitulasi tingkat pencapaian pada uji respon penonton film dokumenter ini dapat dilihat pada Gambar 11.

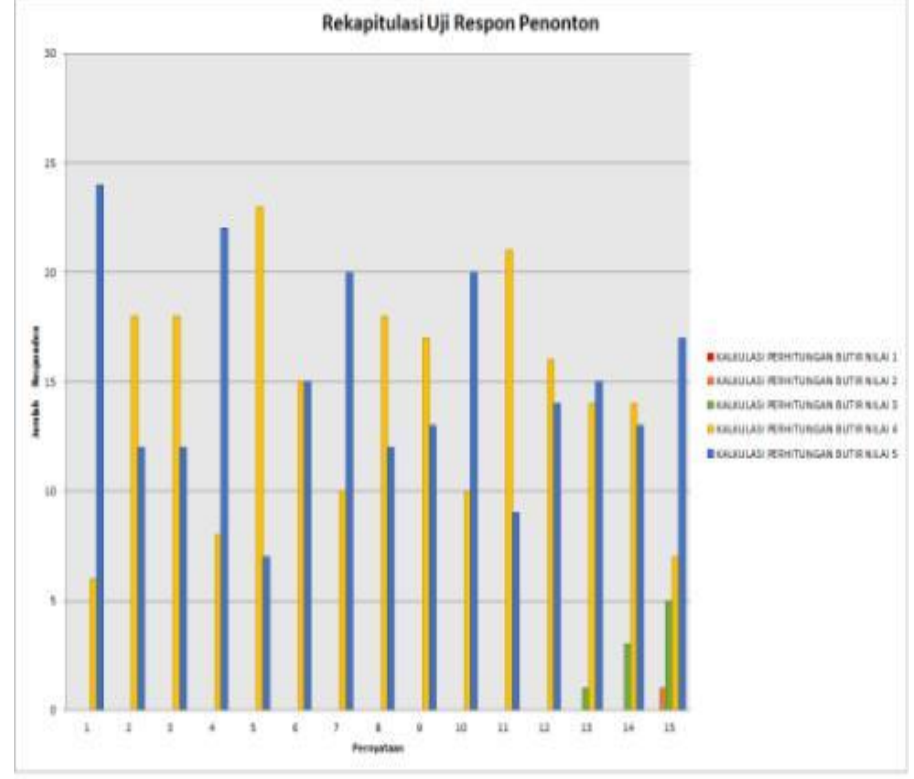

Gambar 11. Hasil Rekapitulasi Uji Respon Penonton.

Dalam pembuatan film dokumenter seni tari gandrung "tarian pembangkit semangat bumi blambangan" tidak lepas dari berbagai kendala. Adapun kendala-kendala yang dihadapi salah satunya yaitu keterbatasan dokumentasi tentang beberapa acara seni tari gandrung dan yang menjadi tempat pemetasan seni tari gandrung yang berakibat pada kurangnya video ilustrasi pada pengenalan seni tari gandrung tersebut. Namun, hal tersebut dapat diatasi penulis dengan mencari dokumentasi tersebut di internet. Hasil shoot video-video tersebut didapatkan pada website dengan tetap mencantumkan sumber pada film dokumenter seni tari gandrung "tarian pembangkit semangat bumi blambangan", dengan hal tersebut, kendala dapat diatasi dengan baik. Selain itu terdapat kendala lain yaitu menentukkan jadwal untuk shooting wawancara dengan narasumber, di mana beberapa narasumber memiliki kesibukkan yang tidak sedikit sehingga penulis agak kesulitan dalam menentukkan jadwal untuk shooting, namun kendala tersebut dapat teratasi dengan menjalin komunikasi yang baik dengan narasumber sehingga jadwal shooting bisa dikoordinasikan dengan baik.

Dalam pengambilan gambar, penulis juga mengalami beberapa kendala seperti banyaknya suara noise yang masuk karena kebanyakan pengambilan gambar dilakukan di luar ruangan. Namun dengan memanfaatkan software Adobe Audition CS 6 untuk mengurangi noise suara, kendala tersebut dapat diatasi. Selain itu penulis juga mendapatkan kendala dalam hal mengumpulkan crew dalam proses shooting, namun dapat diatasi dengan memaksimalkan perlatan yang ada. Dalam teknik editing video juga terdapat beberapa kendala yaitu kesulitan dalam mengatur resolusi warna video, ini dikarenakan pada saat pengambilan gambar menggunakan kamera berbeda jenis sehingga ketajaman warna yang dihasilkan dari masing- 


\section{ISSN \\ Kumpulan Artikel Mahasiswa Pendidikan Teknik Informatika}

(KARMAPATI)

masing kamera tidak sama. Namun kendala tersebut dapat diatasi dengan cara menambahkan effect Fast Color Corrector serta mengatur Brightness \& Contrast pada masing-masing video.

Film dokumenter ini dapat menyampaikan realitas yang ada di lapangan dengan inovasi yang lebih menarik terhadap seni tari tradisional Banyuwangi khususnya seni tari gandrung. Film dokumenter seni tari gandrung "tarian pembangkit semangat bumi blambangan" ini dibuat dengan manfaat untuk memberikan wawasan bagi penonton terkait pengenalan Desa Kemiren, pengenalan seni tari gandrung Desa Kemiren, sejarah seni tari gandrung terutama yang ada di Desa Kemiren, serta perkembangannya hingga saat ini. Sehingga, masyarakat yang sebelumnya kurang mengetahui seni tari gandrung Desa Kemiren secara keseluruhan, setelah menonton film ini setidaknya jadi lebih mengenal Desa Kemiren, lebih mengenal seni tari gandrung Desa Kemiren, mengetahui sejarah seni tari gandrung terutama yang ada di Desa Kemiren serta mengetahui perkembangannya hingga saat ini. Karena dalam film ini terkandung nilai-nilai kearifan lokal masyarakat Banyuwangi khususnya dalam bidang seni tari tradisional Banyuwangi agar dapat tersampaikan dengan media yang lebih beragam serta inovatif dan menarik sehingga maryarakat lebih mudah untuk mendapatkan informasi khusunya informasi tentang seni tari gandrung terutama yang ada di Desa Kemiren. Dari pembahasan dapat disimpulkan, bahwa informasi yang terdapat pada Film dokumenter seni tari gandrung "tarian pembangkit semangat bumi blambangan" telah tersampaikan dengan baik dan memperoleh respon pencapaian yang baik dari penonton. Penelitian sejenis yang memiliki tujuan sama dengan Film dokumenter seni tari gandrung "tarian pembangkit semangat bumi blambangan" yaitu penelitian putri (2013/ yang berjudul "Perancangan Video Dokumenter Batik Khas di Pekalongan". Bertujuan untuk memperkenalkan batik khas Kota Pekalongan yaitu batik motif Jlamprang dan Buketan. Selain itu sekaligus memberikan informasi tentang batik khas Kota Pekalongan yaitu batik motif Jlamprang dan Buketan kepada masyarakat.

\section{SIMPULAN}

Berdasarkan hasil dari penelitian dan pembahasan penelitian film dokumenter Seni Tari Gandrung "Tarian Pembangkit Semangat Bumi Blambangan", maka penulis dapat menarik kesimpulan bahwa perancangan film dokumenter Seni Tari Gandrung "Tarian Pembangkit Semangat Bumi Blambangan" telah berhasil dilaksanakan dengan menggunakan model cyclic strategy dan menggunakan tahapan produksi film yaitu pra produksi, produksi dan pasca produksi. Pengimplementasian film dokumenter Seni Tari Gandrung "Tarian Pembangkit Semangat Bumi Blambangan" telah sesuai dengan rancangan yang telah dibuat sebelumnya dengan tambahan.
Berdasarkan hasil uji respon film dokumenter Seni Tari Gandrung "Tarian Pembangkit Semangat Bumi Blambangan" terhadap 30 responden yang berasal dari masyarakat terutama generasi muda anggota-anggota sanggar yang ada di Desa Kemiren dan sekitaran wilayah Banyuwangi, diperoleh persentase keseluruhan sebanyak $89,51 \%$. Hasil yang diperoleh ini dikategorikan ke dalam pencapaian baik.

Disarankan dalam pembuatan film dokumenter harus dapat menyampaikan informasi yang realitas dan narasumber yang digunakan harus berkompeten agar hasil yang diperoleh sesuai dengan apa yang dirancang sebelumnya.

Diusahakan untuk menggunakan alat perekam yang sejenis agar resolusi warna tidak jauh berbeda. Dalam proses produksi pula sebelumnya harus menyiapkan jadwal produksi yang baik namun tetap berjaga-jaga akan segala kemungkinan agar jika menemukan masalah atau hambatan bisa segera teratasi dengan baik. Tahap pengujian respon penonton pada penelitian film dokumenter ini menggunakan skala likert. Untuk peneliti selanjutnya bisa menggunakan angket user experience atau sejenis agar dapat mengetahui kelebihan dan kekurangan dari film dokumenter yang telah dibuat. Untuk peneliti lain yang akan melakukan penelitian tentang pembuatan film dokumenter, diharapkan agar bisa membuat film dokumenter kreatif yang di dalam scene film tersebut terdapat unsur konflik.

\section{REFERENSI}

[1] Agni Ariatama. (2008). Job Description Pekerja Film. Jakarta: Fakultas Film dan Televisi Institut Kesenian Jakarta.

[2] Ariatama, A. (2008). Job Description Pekerja Film. Jakarta: Fakultas Film dan Televisi Institut Kesenian Jakarta (FFTV-IKJ).

[3] Bisnis, W. (2017, Mey 3). 14 Tipe Shot Dalam Pengambilan Gambar Film. Dipetik November 12, 2017 , dari webbisnis.com: https://webbisnis.com/14-tipe-shotdalam-pengambilan-gambar-film/amp/

[4] Budiaji, W. (2013). Skala Pengukuran dan Jumlah Respon Skala Likert. Jurnal Ilmu Pertanian dan Perikanan, Volume 2, Nomor 2 (hlm. 127-133).

[5] Darmawan, I. (2011, Desember 27). Unsur Suara Dalam Film. Dipetik Agustus 12, 2017, dari http://www.iwandarmawan.com/unsursuaradalamfilm/

[6] Effendy, O. U. (2003). Ilmu, Teori dan Filsafat Komunikasi. Bandung: Citra Aditya Bakti.

[7] Faruq, I. (2016, November 28). Membuat Analisis SWOT: Pengertian, Manfaat dan Contoh Penerapannya. Dipetik Mei 15, 2018, dari Centrausaha.com: https://centrausaha.com/analisis-swot/

[8] Gani, R. (2013). Jurnalistik Foto. Bandung: Simbiosa Rekatama Media. 
[9] Hapsari, C. S. (2015). Pembuatan Film Dokumenter tentang Cerita dan Sejarah Tari Langen Kusuma Banjaransari Puro Pakualaman di Yogyakarta. 3.

[10] Hartanto, D. D. (2003). Pemilihan Tipografi Pada Judul Film. Desain Komunikasi Visual, Volume 5, Nomor 2 (hlm. 201-2013).

[11] Hermawan, I. M. (2015). Tradisi Tari Sanghyang Bojog di Desa Pakraman Bugbug, Karangasem, Bali (Latar Belakang, Fungsi dan Potensinya Sebagai Sumber Belajar Sejarah Kebudayaan di SMA). Jurnal Pendidikan Sejarah, Volume 3, Nomor 1 (hlm. 1-15).

[12] Mertasari, L. A. (2015). Fungsi Tradisi Seblang Terhadap Kehidupan Sosial dan Keagamaan Masyarakat Desa Bakungan, Kecamatan Glagah, Kabupaten Banyuwangi. Fakultas Ushuluddin dan Pemikiran Islam, Universitas Islam Negeri Sunan Kalijaga Yogyakarta.

[13] Mudjiono, Y. (2011). Kajian Semiotika Dalam Film. Jurnal Ilmu Komunikasi, 1-14.

[14] Narawidia, I. N. (2017). Film Dokumenter Sejarah Drama tari Gambuh Desa Batuan. Kumpulan Artikel Mahasiswa Pendidikan Teknik Informatika (KARMAPATI), Volume 6, Nomor 1 (hlm. 1-11). 